\title{
The Caspian Sea:
}

A Quest for Environmental Security 


\section{NATO Science Series}

A Series presenting the results of activities sponsored by the NATO Science Committee. The Series is published by IOS Press and Kluwer Academic

Publishers, in conjunction with the NATO Scientific Affairs Division.
A. Life Sciences
B. Physics
C. Mathematical and Physical Sciences
D. Behavioural and Social Sciences
E. Applied Sciences
F. Computer and Systems Sciences

1. Disarmament Technologies

2. Environmental Security

3. High Technology

4. Science and Technology Policy

5. Computer Networking
IOS Press

Kluwer Academic Publishers

Kluwer Academic Publishers

Kluwer Academic Publishers

Kluwer Academic Publishers IOS Press

Kluwer Academic Publishers Kluwer Academic Publishers Kluwer Academic Publishers IOS Press

IOS Press

\section{NATO-PCO-DATA BASE}

The NATO Science Series continues the series of books published formerly in the NATO ASI Series. An electronic index to the NATO ASI Series provides full bibliographical references (with keywords and/or abstracts) to more than 50000 contributions from international scientists published in all sections of the NATO ASI Series.

Access to the NATO-PCO-DATA BASE is possible via CD-ROM "NATO-PCO-DATA BASE" with user-friendly retrieval software in English, French and German (WTV GmbH and DATAWARE Technologies Inc. 1989).

The CD-ROM of the NATO ASI Series can be ordered from: PCO, Overijse, Belgium

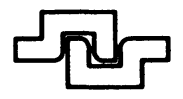

Series 2. Environment Security - Vol. 67 


\section{The Caspian Sea: A Quest for Environmental Security}

edited by

\section{William Ascher}

Center for International Development Research, Terry Sanford Institute of Public Policy,

Duke University,

Durham, North Carolina, U.S.A.

and

\section{Natalia Mirovitskaya}

Institute of Universal History,

Russian Academy of Sciences,

Moscow, Russia, and

Center for International Development Research,

Terry Sanford Institute of Public Policy,

Duke University,

Durham, North Carolina, U.S.A.

Springer-Science+Business Media, B.V. 
Proceedings of the NATO Advanced Research Workshop on The Caspian Sea: A Quest for Environmental Security Venice, Italy

15-19 March 1999

A C.I.P. Catalogue record for this book is available from the Library of Congress.

ISBN 978-0-7923-6219-7 ISBN 978-94-011-4032-4 (eBook)

DOI 10.1007/978-94-011-4032-4

Printed on acid-free paper

\section{All Rights Reserved \\ (C) 2000 Springer Science+Business Media Dordrecht \\ Originally published by Kluwer Academic Publishers in $\mathbf{2 0 0 0}$}

No part of the material protected by this copyright notice may be reproduced or utilized in any form or by any means, electronic or mechanical, including photocopying, recording or by any information storage and retrieval system, without written permission from the copyright owner. 


\section{Contents}

Preface

William Ascher \& Natalia Mirovitskaya................................. ix

Map of the Caspian Sea Region..........................................

List of Abbreviations and Acronyms .......................................iii

Chapter 1. Introduction

Natalia Mirovitskaya \& William Ascher...................................

\section{Part A. What is at Stake in the Caspian: Development versus Environment?}

Chapter 2. Environmental Change and Human Security in the Caspian Region: Threats, Vulnerability and Response Strategies

Marvin S. Soroos.

Chapter 3. International Good Governance and Civilized Conduct among the Caspian States: Oil and Gas as Lever for Prosperity or Conflict

Thomas Waelde

Chapter 4. Regional Developmental Requirements and the Role of Caspian Development

Konstantin Atanesyan

Chapter 5. Ecological Consequences of Oil and Gas Development Igor S. Zonn....

Chapter 6. New Methods for Managing Caspian Sea Level Fluctuations Anatolii V. Frolov

\section{Part B. Caspian Geopolitics}

Chapter 7. The Geopolitics of the Region

Bruce Kuniholm.

Chapter 8. Security and the Environment in the Caspian Sea

Shireen T. Hunter.

Chapter 9. Security Problems in the Caucasus

Alexander Rondeli. 
Chapter 10. The International Politics of Energy in the Caspian Sea Basin:

Russia, Turkey and the Pipeline Project

Andrei Volodin

\section{Part C. Law and Development}

Chapter 11. The Caspian and International Law: Like Oil and Water? Cesare P.R. Romano

Chapter 12. Basic Legal Issues of the Management of Natural Resources of the Caspian Sea

Alexandre N. Vylegjanin.

Chapter 13. Caspian Legal Regime: Dynamics of Kazakhstan's Position Rashid N. Gaisin.

Chapter 14. The "Tug of War" in the Caspian: Legal Positions of the Coastal States

Sergei $V$. Vinogradov

\section{Part D. The Role of Civil Society \& Scientific Institutions}

Chapter 15. Environment and the Development of Civil Society in the Caspian Region: The Role of NGOs

Kate Watters.

Chapter 16. How NGOs Abandoned Governance in the Caspian Region Eric $W$. Sievers.

Chapter 17. The Political Role of Civil Society in Georgia Ivlian Haindrava

Chapter 18. The State of Scientific Research on the Caspian Environment: Russian Data Igor S. Zonn

\section{Part E. Prospects of Effective International Cooperation}

Chapter 19. Regional Cooperation: Lessons for the Caspian Sea Erhard Busek. 
Chapter 20. Technodiplomacy and Environmental Cooperation:

Lessons for the Caspian

William Ascher \& Natalia Mirovitskaya

Chapter 21. Applying Lessons from the Aral Sea Basin:

The Role of Non-State Actors

Erika S. Weinthal.

Chapter 22. National, Subnational, and International Politics:

Environmental Regime-Building in the Caspian Sea

Douglas W. Blum.

Chapter 23. Caspian Environment Programme: Prospects For

Regime Formation and Effectiveness

Eric $W$. Sievers.

\section{Part F. Conclusions}

Chapter 24. Moving toward International Cooperation in the Caspian Region: Insights from the Workshop

Natalia Mirovitskaya \& William Ascher.

Index 


\section{Preface}

This volume is based on the presentations and deliberations of an Advanced Research Workshop (ARW) "Caspian Sea: A Quest for Environmental Security" that was held on March 15-19, 1999, in Venice (Italy). The Workshop was sponsored by the NATO's Division for Scientific and Environmental Affairs, with additional support provided by the Trust for Mutual Understanding (USA). It was organized by Duke University's Center for International Development Research with the guidance of the International Committee of scientists from Russia, United States, Georgia and Italy and organizational assistance rendered by Venice International University.

The Caspian Sea region is of profound importance from the perspective of global and regional environmental security. New geopolitical and economic circumstances have created a mixture of competition, reluctant collaboration, and legal, political, economic and ideological wrangling. There is an intense debate over how the Caspian and its resources should be divided among littoral states and how these resources are to be developed. While most littoral states and the international companies strive to develop the area's immense hydrocarbon potential, it is clear that the Caspian's unique and fragile ecosystem is at risk. In view of the extreme complexity of the issue and the vital economic, political and environmental interests involved, the purpose of the Workshop was to provide the most recent scientific assessments of the environmental threats in the region and also articulate standpoints of different stakeholders from littoral states as well as diverse approaches of interest groups from other nations currently involved or potentially affected by Caspian developments. The focus of the Workshop reflected the progress of earlier NATO Advanced Research Workshop (Moscow, 1994), which clarified the natural-science-based environmental risks in the Caspian. It also reflected the growing awareness of economic limitations in the Caspian region. It now appears that commercially exploitable Caspian oil reserves are of smaller magnitude than was believed only two years ago, because of both disappointing results from drilling and the decline in world oil prices. There has also been increased appreciation for the complexity and huge costs involved in establishing a viable pipeline network. While several of the papers in this volume offer updated information on the environmental situation and on prospects for Caspian oil and general economic developmert, the Workshop basically took as a given that the region faces many conventional security issues, while also undergoing both economic disappointment and severe environmental stress. Therefore the challenge of this Workshop was to address the almost untouched questions of how to foster cooperation in resource-sharing and environmental security issues and how to structure international cooperation to ensure its effectiveness.

The Workshop brought together a distinguished group of experts in different areas and disciplines. Participants were selected from the governmental institutions of littoral states as well as research institutes, universities, business community, media and nongovernmental organizations of sixteen countries. The professional specialization of the participants varied from ecology, geography, hydrology and environmental studies to political science, law, international relations and security studies, economics, and business administration. Such diverse representation made it possible to provide multidisciplinary assessments of the relationships among international security, politics, 
environmental change, economic development, and the legal status of the Caspian. It also provided for a vivid exchange of perspectives by different interest groups from Russia, Azerbaijan, Kazakhstan, Turkmenistan, Georgia, Armenia, the United States, Great Britain and other nations presently or potentially involved in Caspian economic, political and environmental developments. Attendance of representatives of international organizations provided the Workshop with a much-desired comparative perspective and was conducive to expanding contacts between major stakeholders in this sensitive region. Observers from the United States, Greece, Germany, Belgium and Italy also provided valuable input into the Workshop's discussions and activities of the working groups.

In addition to those whose chapters comprise this book, we are grateful to the other participants who chaired sessions, served as discussants and working group leaders, and gave papers that for different reasons are not included into this volume. They are (in alphabetical order) Ruslan Aliev, Khabibulla Atamuradov, Kinat Bozumbaev, Galina Churkina, Karine Danielyan, Michael Glantz, Henry Huttenbach, Askhat Kaiumov, Ioannis Kinnas, Francis Lethem, Mirzakhan Mansimov, Richard Matthew, Vera Mischenko, Bijan Mossavar-Rahmani, Ignazio Musu, Shahin Panachov, Renat Perelet, DJ Petersen, Eileen Petzold-Bradley, Ludmila Shabaeva, Edward Smith and Detlef Sprintz.

This Workshop and publication of proceedings could not have undertaken without support of many people. Bruce Kuniholm, Vice-Provost for Academic and International Affairs at Duke University, encouraged us to proceed with this project and rendered support of his office for it. We are especially grateful to the staff of the Center for International Development Research at Duke University - Jonathan Abels, Susan Elinoff and Malcolm Leggett- who worked long hours to ensure that the Workshop went effectively and smoothly. In Venice, Andrea Del Mercato and Alessandro Spezzamonte from the Venice International University were particularly helpful. Our sincere thanks go also to Eliza Close and Kate Watters (ISAR), Amy Evans (the World Bank), Bijan Mossavar-Rahmani (Mondoil), David Usupashvili (Georgian Union of Young Lawyers) and Igor Zonn (UNEPCom-Russia) who helped us with their ideas and contacts at different phases of designing and organizing this meeting. After the Workshop, Elizabeth de Santo made a very important contribution to summarizing the meeting sessions and smoothing the language in the chapters by non-native-English-speaking authors. Dmitry Mirovitsky did a great job with preparation of the camera-ready copy of this book.

We are grateful to all these persons and institutions for their support and assistance. However, responsibility for whatever problems remain is totally ours.

We hope that this book will make a valid contribution to the on-going debates on environmental security and its prospects in the Caspian region.

William Ascher and Natalia Mirovitskaya

Editors \& Co-Directors of the NATO ARW 
Map of the Caspian Region

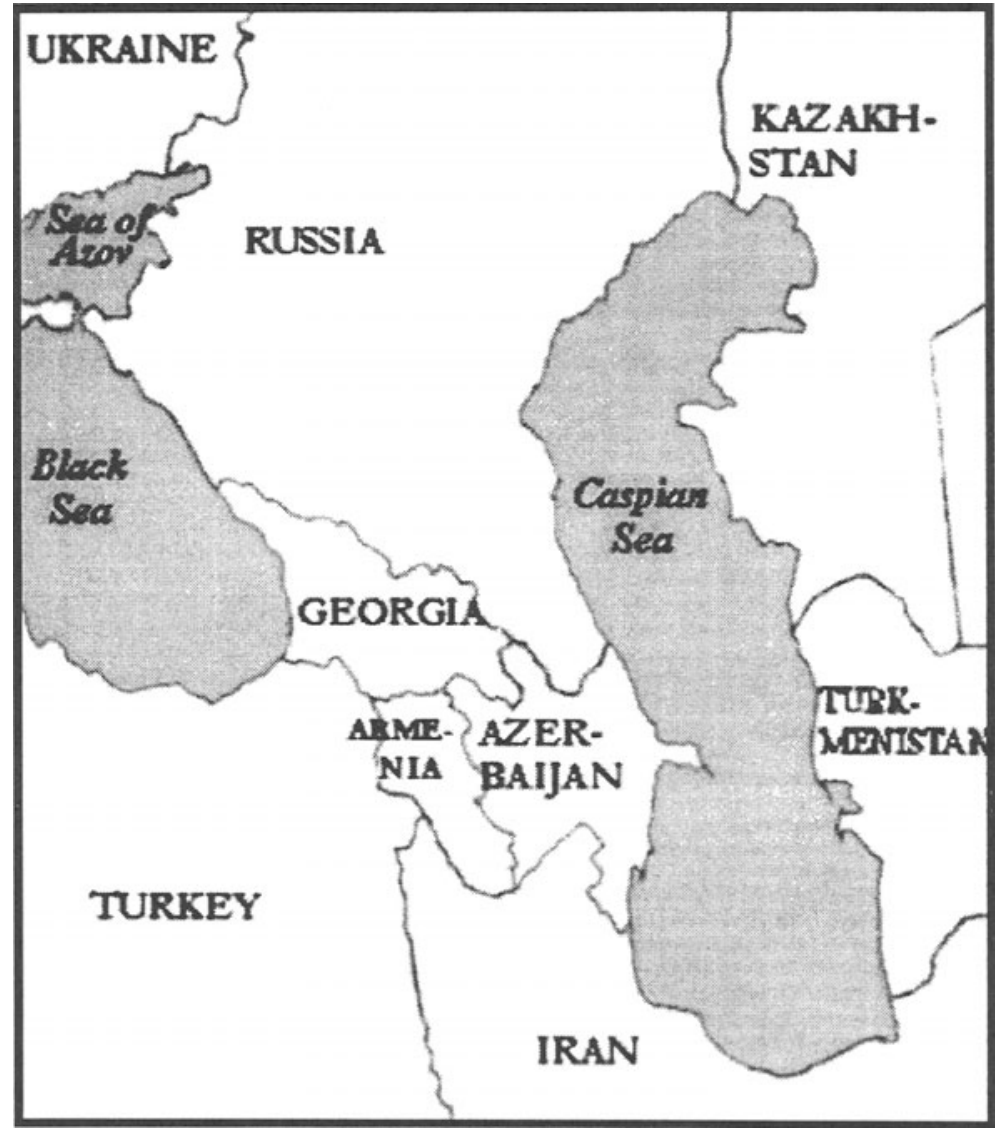




\section{List of Abbreviations and Acronyms}

\begin{tabular}{|c|c|}
\hline AIOC & Azerbaijan International Operating Company \\
\hline ASBP & Aral Sea Basin Program \\
\hline $\mathbf{B} / \mathbf{d}$ & barrels per day \\
\hline Bef & billions of cubic feet \\
\hline BSEC & Black Sea Economic Cooperation \\
\hline CBD & Convention on Biological Diversity \\
\hline CCD & Convention to Combat Desertification \\
\hline $\mathrm{CCO}$ & Caspian Cooperation Organization \\
\hline CEI & Central European Initiative \\
\hline CEP & Caspian Environment Programme \\
\hline CIS & Commonwealth of Independent States \\
\hline CITES & Convention to Regulate International Trade in Endangered Species \\
\hline CMS & Convention on Migratory Species \\
\hline CPC & Caspian Pipeline Consortium \\
\hline CSCE & Conference for Security and Cooperation in Europe \\
\hline EBRD & European Bank for Reconstruction and Development \\
\hline $\mathbf{E U}$ & European Union \\
\hline FCCC & Framework Convention on Climate Change \\
\hline FCCS & $\begin{array}{l}\text { Framework Convention for the Protection and Sustainable Management } \\
\text { of the Caspian Environment and its Resources }\end{array}$ \\
\hline FSU & Former Soviet Union \\
\hline GEF & Global Environmental Facility \\
\hline Gosplan & USSR State Planning Committee \\
\hline ICAS & Interstate Council for Addressing the Aral Sea Crisis \\
\hline ICKKU & Interstate Council for Kazakhstan, Kyrgyzstan, and Uzbekistan \\
\hline ICSDSTEC & $\begin{array}{l}\text { Interstate Commission for Socio-Economic Development and Scientific, } \\
\text { Technical, and Ecological Cooperation }\end{array}$ \\
\hline IFAS & International Fund for the Aral Sea \\
\hline IGOs & international governmental organizations \\
\hline IMF & International Monetary Fund \\
\hline IWC & International Whaling Commission \\
\hline LRTAP & Convention on Long Range Transboundary Air Pollution \\
\hline MFA & Ministry of Foreign Affairs \\
\hline NACC & North Atlantic Cooperation Council \\
\hline NATO & North Atlantic Treaty Organization \\
\hline NEC & National Environment Center \\
\hline NIS & Newly Independent States \\
\hline NGOs & non-governmental organizations \\
\hline OSCE & Organization for Security and Cooperation in Europe \\
\hline PFP & Partnership for Peace \\
\hline SOCAR & State Oil Company of the Azerbaijan Republic \\
\hline SECI & Southeast European Cooperative Initiative \\
\hline SPECA & Special Program for the Economies of Central Asia \\
\hline
\end{tabular}


xiv

TACIS Technical Assistance to the Commonwealth of Independent States Programme

Tef trillions of cubic feet

TRACECA Transport Corridor Europe Caucasus Asia

UNCLOS United Nations Convention on the Law of the Sea

UNDP United Nations Development Program

UN/ECE United Nations Economic Commission for Europe

UNEP United Nations Environmental Program

USAID United States Agency for International Development 